\title{
PENERJEMAHAN KATA MAJEMUK NOMINA BAHASA INGGRIS KE DALAM BAHASA INDONESIA
}

\author{
Made Dharma Susena Suyasa \\ Jurusan D3 Bahasa Inggris \\ Universitas Pendidikan Ganesha \\ E-mail: madedhar@yahoo.com
}

\begin{abstract}
Abstrak
Dalam proses penerjemahan kata majemuk nomina bahasa Inggris ke dalam bahasa Indonesia, berbagai masalah dapat muncul. Penelitian ini bertujuan untuk mengungkap kata majemuk nomina yang sering digunakan dalam teks berita serta jenis kata majemuk nomina yang produktif dalam teks berita, dan mengkaji secara mendalam prosedur yang digunakan oleh penerjemah untuk mengatasi masalah yang muncul dalam proses penerjemahan kata majemuk nomina bahasa Inggris ke dalam bahasa Indonesia. Sumber data dalam penelitian ini adalah lima puluh enam teks berita dalam Bahasa Inggris dan terjemahannya dalam Bahasa Indonesia. Pengumpulan data dilakukan dengan pembuatan korpus data yang kemudian dianalisis berdasarkan unsurnya yang membentuk kata majemuk tersebut. Kemudian, analisis diikuti dengan membandingkan makna kata majemuk nomina dalam bahasa Inggris dan terjemahannya dalam bahasa Indonesia. Hasil penelitian menunjukkan bahwa ada enam puluh tujuh kata majemuk nomina yang digunakan dalam lima puluh enam teks berita. Tujuh belas kata majemuk tersebut merupakan kata majemuk baru. Secara keseluruhan, kata majemuk tersebut dapat diklasifikasikan menjadi empat jenis kata majemuk. Hasil penelitian juga menunjukkan bahwa ada dua belas prosedur penerjemahan yang digunakan oleh penerjemah dalam penerjemahan kata majemuk nomina bahasa Inggris ke dalam bahasa Indonesia.
\end{abstract}

Kata kunci: penerjemahan, kata majemuk

\begin{abstract}
Some problems might evolve in translating English compound nouns into Indonesian language. This research was aimed at finding out some commonlyused English compound nouns in news articles, the most productive compound noun in news articles, and examining thoroughly the procedures used by some translators to face some problems in translating English compound nouns into Indonesian language. Fifty six English articles including their translation in Indonesian Language were extracted as the source of data in this research. The data were gathered in a corpus. The analysis was done by examining the categories of English compound words based on their elements and by comparing their meanings. The results of this research show that there are sixty seven compund nouns used in the articles. Seventeen compounds are the new compounds which have not been listed in dictionary. All of the compound nouns
\end{abstract}


show four different types. It ia also shown that there are twelve procedures used by translators in translating English compund nouns into Indonesian language.

Keywords: translation, compound word.

\section{PENDAHULUAN}

Pada era globalisasi ini, perkembangan kebudayaan baik dalam bidang ilmu pengetahuan maupun dalam bidang seni sudah sangat pesat, terutama pada negara-negara maju. Negara berkembang, seperti Indonesia perlu menyerap berbagai perkembangan tersebut sehingga nantinya dapat ikut bersaing di kancah internasional. Namun, sebagaimana yang kita ketahui, sebagian besar karyakarya ilmiah maupun non-ilmiah oleh negara maju diplublikasikan di dunia dengan menggunakan bahasa Inggris.

Sayangnya, sebagian besar masyarakat Indonesia tidak memiliki kemampuan bahasa Inggris yang memadai, sehingga proses penyerapan kebudayaan antara Indonesia dengan negara-negara lain di dunia menjadi tidak maksimal dan lambat. Jika hal ini dibiarkan berlarut-larut, Indonesia akan tertinggal jauh dari negara-negara maju. Hal inilah yang membuat penerjemahan menjadi penting di Indonesia. Bentuk kegiatan tersebut dapat menjembatani gap di atas. Dengan adanya karyakarya terjemahan, masyarakat Indonesia yang tidak dapat memahami bahasa Inggris dapat mengikuti perkembangan yang terjadi di dunia.

Namun, penerjemahan tidaklah mudah. Dalam proses penerjemahan, berbagai masalah akan muncul. Hoed (2006: 40) mengutarakan bahwa bahasa memiliki sifat sui generis, yakni setiap bahasa memiliki sitem dan strukturnya sendiri yang khas untuk dirinya. Oleh sebab itu, dalam proses penerjemahan, perbedaan antara dua bahasa yang terlibat seringkali menimbulkan masalah. Hal ini dapat dipahami karena sifat sui generis-nya itulah setiap bahasa memiliki cara tersendiri untuk mengelompokkan komponen semantisnya. Konsekuensinya, padanan satu lawan satu akan sulit dicapai dalam proses penerjemahan. Hal ini mengimplikasikan bahwa seorang penerjemah harus benar-benar memahami perbedaan antara bahasa sasaran (selanjutnya akan disebut Bsa) dan bahasa sumber (selanjutnya akan disebut Bsu) dan teknik penerjemahan dalam upaya menghasilkan terjemahan yang baik dalam Bsa.

Salah satu satuan bahasa yang harus diketahui oleh penerjemah adalah kata majemuk. Kata majemuk secara sederhana dapat didefinisikan sebagai kombinasi dua kata atau lebih sehingga menghasilkan kata yang baru (Benczes, 2006:7). Sehubungan dengan itu, kata majemuk sering digunakan dalam bahasa Inggris. Bahkan kata majemuk baru yang belum terdaftar dalam kamus dapat bermunculan setiap hari karena jenis kata tersebut merupakan proses pembentukan kata yang sangat produktif (cf. Matthews, 1991: 15 dan Harley, 2006:99).

Terlebih lagi, Dressler (dalam Libben dan Jarema 2006: 26) mengemukakan bahwa makna suatu kata majemuk tidak dapat diprediksi oleh unsur yang membentuknya. la memberikan contoh bahwa iron pipe 
bermakna a pipe made of iron, sedangkan stove pipe adalah a pipe of a stove. Dalam hal itu, ia mengemukakan bahwa kata majemuk berbeda dengan frasa, yakni tata bahasa tidak dapat dijadikan dasar untuk memaknai kata majemuk. Mengingat bahwa bahasa memiliki sifat sui generis, hal ini tentu saja merupakan suatu masalah yang harus dihadapi oleh seorang penerjemah.

Lebih jauh, Bauer (1988: 33) mengemukakan dua jenis kata majemuk, yakni kata majemuk endosentris (endocentric compound word) dan kata majemuk eksosentris (excocentric compound word). Menurutnya, kata majemuk endosentris adalah kata majemuk yang memiliki kepala (headed compound word), misalnya sea bird adalah a kind of bird karena itu bird adalah kepala (head) kata majemuk tersebut. Oleh karena itu pula ia beranggapan bahwa kata majemuk endosentris merupakan hiponim unsur kepala yang membentuknya. Sebaliknya, Kata majemuk eksosentris adalah kata majemuk yang tidak memiliki kepala (headless compound word), misalnya egg-head yang maknanya a person who is very intelligent and is only interested in studying. Dengan demikian, makna kata tersebut tidak ada hubungannya dengan unsur yang membangunnya.

Sementara itu, Katamba (1993: 291-294) mengemukakan bahwa bentuk kata majemuk dalam bahasa Inggris memiliki persamaan dengan bentuk frasa dalam bahasa Inggris. Menurutnya, hal yang dapat menjadi unsur pembeda antara kata majemuk dan frasa adalah unsur fonologi kedua bentuk tersebut. Kata majemuk umumnya memiliki tekanan pada unsur yang berada di sebelah kiri, sedangkan frasa memiliki tekanan pada unsur yang berada di sebelah kanan. Namun, unsur pembeda tersebut hanya dapat diaplikasikan pada ragam lisan. Lebih jauh, Katamba (1993:294) juga mengemukakan bahwa secara ortografi, tidak ada sistem yang konsisten dalam penulisan kata majemuk.

Sehubungan dengan itu, Biber et al. (1999: 362) meneliti distribusi kata majemuk bahasa Inggris. Dalam penelitiannya terungkap bahwa kata majemuk sangat umum digunakan dalam ragam tulis, khususnya pada laras jurnalistik. Hal tersebut disebabkan tempat penulisan yang terbatas, sehingga kata majemuk umum digunakan untuk memperpendek konstruksi klausa yang lebih panjang, misalnya a racially-motivated attack sebagai alih-alih an attack that was motivated by racism.

Di lain kesempatan, McCarthy (2002: 59-65) mengatakan bahwa menurut bentuknya, kata majemuk dalam bahasa Inggris dapat diklasifikasikan menjadi tiga kategori, yakni kata majemuk yang berkategori nomina (compound noun), kata mejemuk yang berkategori verba (compound verb), dan kata majemuk yang berkategori adjektif (compound adjective). Selanjutnya, ia menjelaskan lebih jauh lagi bahwa ketiga kategori kata majemuk tersebut dapat dikelompokkan lagi menurut kategori unsur yang membangunnya.

Lebih jauh lagi, Wilson (dalam Harmelink, 2012: 25-6) mengemukakan bahwa makna kata adalah konsep, dan konsep tersebut merepresentasikan objek, peristiwa, sifat yang ada di dunia 
ini. Pernyataan tersebut dapat diartikan bahwa seorang penulis akan selalu menggunakan kata-kata untuk menyampaikan sesuatu yang ada di benaknya terkait dengan segala hal yang ada di dunia ini. Pengertian ini menunjukkan bahwa makna sebuah kata akan terkait dengan konteks terdekat maupun konteks di luar konteks linguistik.

Berdasarkan pendapat yang dikemukakan para ahli tersebut, dapat disimpulkan bahwa beberapa jenis kata majemuk, khusunya kata majemuk yang berkategori nomina, memiliki karakteristik bentuk yang sama dengan frasa. Namun, makna kata majemuk tersebut tidak dengan mudah didapat berdasarkan unsur yang membentuknya. Banyak kata majemuk nomina yang tidak bisa diprediksi berdasarkan unsur yang membangunnya. Dengan demikian, hal tersebut tentu saja akan menimbulkan masalah dalam proses penerjemahan kata majemuk nomina bahasa Inggris ke dalam bahasa Indonesia.

Sehubungan dengan itu, Newmark (1988: 81-93) mengemukakan bahwa seorang penerjemah dapat menggunakan beberapa prosedur untuk mengatasi beberapa masalah dalam proses penerjemahan, khususnya masalah penerjemahan yang muncul pada satuan terjemahan yang lebih kecil daripada keseluruhan teks.

Prosedur pertama adalah transference (peminjaman murni), yakni pemakaian kata dalam Bsu apa adanya dalam teks terjemahan. Prosedur yang kedua adalah naturalization (penyerapan), yakni meminjam kata dalam Bsu dalam teks Bsa dengan menyesuaikan ejaan dan pelafalan dalam Bsa.

Yang ketiga adalah cultural equivalent (pemadanan budaya). Dalam prosedur ini, kata yang bermuatan budaya dalam Bsu diterjemahkan dengan kata yang bermuatan budaya lokal dalam Bsa. Misalnya, sincierly yours menjadi hormat kami.

Yang keempat adalah functional equivalent (pemadanan fungsional). Dalam prosedur ini, kata yang bermuatan budaya dalam Bsu diterjemahkan dengan kata yang netral atau tidak bermuatan budaya, misalnya civil marriage menjadi ikatan sesama jenis.

Prosedur yang kelima adalah descriptive equivalent (pemadanan deskriptif). Dalam prosedur ini, kata dalam Bsu diterjemahkan dengan mendeskripsikannya atau melihat fungsinya, misalnya civil marriage diterjemahkan menjadi perkawinan sesama jenis yang diakui oleh Negara tetapi tidak diakuai oleh agama atau stand jack diterjemahkan menjadi pengungkit.

Yang keenam adalah synonymy (pemadanan yang bersinonim). Dalam prosedur ini, kata dalam Bsu diterjemahkan dengan sinonim dalam Bsa, misalnya, superior company menjadi perusahan besar.

Yang ketujuh adalah throughtranslation (penerjemahan harfiah). Dalam prosedur ini, kata dalam Bsu diterjemahkan secara harfiah dalam Bsa, misalnya ice cream menjadi es krim.

Kemudian, prosedur yang kedelapan adalah sift (pergeseran). la mengemukakan bahwa pergeseran atau transposisi adalah prosedur penerjemahan yang berkaitan dengan 
perubahan bentuk gramatikal dari bahasa sumber ke dalam bahasa sasaran.

Prosedur yang kesembilan adalah modulation (modulasi). Ini adalah prosedur penerjemahan yang melibatkan pengubahan sudut pandang, perspektif, atau kategori pemikiran (Newmark dalam Hoed et al., 1993: 246). Contoh untuk prosedur ini misalnya don't worry about it diterjemahkan menjadi lupakan saja (kuncara et al., 2013: 2).

Yang kesepuluh adalah recognized translation. Dalam prosedur ini, kata Bsu diterjemahkan dengan kata terjemahan yang sudah lazim digunakan baik dalam surat kabar ataupun lembaga tertentu, misalanya state gazette dalam konteks akta kelahiran menjadi lembaran negara.

Prosedur yang kesebelas adalah translation label. Dalam prosedur ini, kata dalam Bsu dipadankan secara sementara karena belum ada padanan yang sangat mendekati kata dalam Bsu tersebut. Misalnya, transference dipadankan oleh penulis menjadi peminjaman murni. Umumnya, kata Bsu tetap dituliskan dalam teks terjemahan seperti 'peminjaman murni (transference)'.

Prosedur yang keduabelas adalah Compensation (kompensasi). Dalam prosedur ini, ada sesuatu efek yang hilang pada kata dalam Bsu jika diterjemahkan ke dalam Bsa, misalnya hilangnya efek suara dalam aliterasi (coffee corner menjadi pojok kopi).

Yang ketigabelas adalah componential analysis (pemadanan dengan salah satu komponen makna). Dalam prosedur ini, kata Bsu dipadankan dengan salah satu komponen maknanya, misalnya chestnut menjadi kacang.

Yang keempat belas adalah reduction and expansion (pengurangan dan penambahan). Dalam prosedur ini, Bsu dipadankan dengan pengurangan atau penambahan, misalnya I want you to eat well, to rest and sleep menjadi Saya ingin kamu menyantap makanan yang bergizi, istirahat, dan banyak tidur (kuncara et al., 2013: 3) atau writ and warrant menjadi surat perintah.

Prosedur yang kelimabelas adalah paraphrase (paraphrase). Dalam prosedur ini, kata Bsu yang tersirat diterjemahkan menjadi tersurat. Misalnya contoh yang diambil dari kuncara et al. berikut ini give him something, to ern his leaving, a good living menjadi berikan ia pekerjaan agar bisa mendapatkan nafkah untuk keluarganya, kehidupan yang layak.

Prosedur yang keenambelas adalah couplet, triplet, quadruplet. Prosedur ini merupakan prosedur yang menggabungkan dua prosedur atau lebih, misalnya prosedur terjemahan harfiah dan prosedur transposisi.

Yang ketujuhbelas adalah notes, addition, dan glosses. Prosedur ini adalah penambahan catatan atas terjemahan. Catatan tambahan tersebut dapat diberikan dalam badan teks terjemahan ataupun di letakkan di catatan kaki.

Berdasarkan paparan singkat tersebut, prosedur penerjemahan kata majemuk dalam bahasa Inggris ke dalam bahasa Indonesia menjadi penting untuk dikaji lebih dalam. Dalam artikel ini penulis memfokuskan penelitian ini pada prosedur yang digunakan oleh penerjemah dalam penerjemahan kata majemuk nomina 
dalam bahasa Inggris ke dalam bahasa Indonesia. Dengan demikian, pertanyaan penelitian ini adalah; 1) kata majemuk nomina apa saja yang sering digunakan dalam teks berita berbahasa Inggris?; 2) kata majemuk nomina bahasa Inggris apa saja yang belum tercatat dalam kamus?; 3) prosedur apa saja yang digunakan penerjemah dalam penerjemahan kata majemuk nomina bahasa Inggris ke dalam bahasa Indonesia?

Tujuan penelitian ini adalah mengetahui kategori kata majemuk nomina bahasa Inggris yang umum digunakan dalam teks berita; kategori kata majemuk nomina bahasa Inggris yang produktif dalam teks berita; dan prosedur yang digunakan oleh penerjemah dalam penerjemahan kata majemuk tersebut ke dalam bahasa Indonesia.

\section{METODE}

Penelitian ini merupakan penelitian deskriptif kualitatif. Sumber data dalam penelitian ini mencakup lima puluh enam artikel berbahasa Inggris dan terjemahannya dalam bahasa Indonesia yang diambil dari laman bbc.

Ada beberapa instrumen yang digunakan dalam pengumpulan data. Yang pertama adalah peneliti sebagai human instrument. Instrumen kedua adalah Kamus Besar Bahasa Indonesia dan Oxford Advance Learner's Dictionary (OALD). Kamus tersebut digunakan untuk menganalisis makna kata majemuk nomina bahasa Inggris dan terjemahannya dalam bahasa Indonesia sehingga tampak prosedur yang digunakan dalam penerjemahannya. Pendapat Newmark (1988: 81-93) tentang prosedur penerjemahan menjadi dasar analisis terjemahan kata majemuk nomina bahasa Inggris dalam bahasa Indonesia. Sebagai pendukung dalam analisis penerjemahan kata majemuk tersebut, pendekatan yang dikemukakan McCarthy (2002: 59-65) dan Lieber (2009: 43) tentang kata majemuk nomina bahasa Inggris dijadikan ancangan analisis.

Pengumpulan data dilakukan melalui beberapa tahap. Yang pertama adalah membaca teks Bsu dan teks Bsa. Selanjutnya adalah tahap identifikasi data. Dalam hal ini, identifikasi data dilakukan berdasarkan ortografi kata majemuk dalam BSu (cf. Katamba, 1993: 291-4), dan teknik penyisipan adjektif di antara unsur kata majemuk nomina dalam BSu (Lieber, 2009: 43). Selanjutnya diikuti tahap transkripsi data.

Analisis data dilakukan bertahap. Yang pertama adalah analisis setiap unsur kata majemuk nomina ke dalam kelompok-kelompok yang lebih spesifik dan diikuti oleh terjemahannya dalam Bsa. Tahap selanjutnya adalah pengelompokkan kata majemuk nomina $\mathrm{BSu}$ berdasarkan unsur yang membentuk kata majemuk tersebut. Kemudian, diikuti oleh analisis makna yang tercakup dalam kata majemuk nomina bahasa Inggris dan terjemahannya dalam bahasa Indonesia. Tahap terakhir adalah analisis prosedur yang digunakan dalam proses penerjemahan kata majemuk tersebut.

\section{HASIL DAN PEMBAHASAN}

Berdasarkan analisis, hasil penelitian ini menunjukkan ada 67 kata majemuk nomina bahasa Inggris yang 
digunakan dalam teks berita yang menjadi sumber data dalam penelitian ini. Berdasarkan unsur yang membentuknya, kata majemuk nomina tersebut dapat diklasifikasikan menjadi 4 kategori, yakni nomina + nomina; adjektif + nomina; verba + nomina; dan preposisi + nomina. Tujuhbelas di antaranya merupakan kata majemuk nomina baru, yakni kata majemuk yang belum tercatat dalam kamus yang digunakan sebagai instrumen dalam penelitian ini. Hasil penelitian juga menunjukkan bahwa ada 12 prosedur yang digunakan oleh penerjemah dalam penerjemahan kata majemuk nomina bahasa Inggris ke dalam bahasa Indonesia.

Prosedur tersebut mencakup prosedur pemadanan deskriptif, transposisi, pemadanan budaya, pengurangan, peminjaman murni, penerjemahan yang dikenal, parafrasa, penggunaan sinonim, modulasi, penerjemahan berlabel, komponensial analisis, dan prosedur couplet. Prosedur yang terakhir mencakup prosedur naturalisasi + harfiah, naturalisasi + transposisi, deskriptif + penambahan, harfiah + transposisi, pemadanan deskriptif + transposisi, peminjaman murni + transposisi, parafrasa + transposisi, pengurangan + analisis komponensial, dan transposisi + penggunaan sinonim. Agar lebih jelas, temuan penelitian ini diperikan berdasarkan jenis kata majemuk nomina tersebut.

\section{Kata Majemuk Nomina + Nomina}

Kata majemuk nomina + nomina adalah salah satu kata majemuk nomina yang terdiri atas dua unsur yang setiap unsurnya berkelas kata nomina (McCarthy, 2002:61-3). Hasil penelitian menunjukkan bahwa terdapat empat puluh lima kata majemuk jenis ini dan 10 prosedur yang digunakan oleh penerjemah. Untuk lebih jelasnya, kata majemuk tersebut dapat dilihat pada tabel 1 berikut ini.

Tabel 1 Kata Majemuk Nomina + Nomina dan Prosedur Penerjemahannya

\begin{tabular}{clll}
\hline No & BSu & Bsa & Prosedur \\
\hline 1 & Lieutenant General & Letnan Jendral & Naturalisasi dan harfiah \\
2 & Football & sepak bola & Pemadanan deskriptif \\
3 & World Cup & Piala Dunia & Transposisi \\
4 & money-laundering* & pencucian uang & Transposisi \\
5 & queue-jumping & melompat di antrean & Transposisi \\
6 & drink-driving & mabuk sambil menyetir & Pemadanan deskriptif \\
7 & Schoolchildren & anak-anak sekolah & Transposisi \\
8 & field trip & karya wisata & Pemadanan budaya \\
9 & oil rig & alat pengeboran & Pengurangan \\
10 & Airstrike & serangan udara & Transposisi \\
11 & Battleground & wilayah perang & Transposisi \\
12 & Facebook & Facebook & Peminjaman murni \\
13 & social networking site & situs media sosial & Pemadanan yang dikenal \\
14 & The United State & Amerika Serikat & Pemadanan yang dikenal \\
15 & Milestone & tonggak penting & Pemadanan deskriptif
\end{tabular}




\begin{tabular}{|c|c|c|c|}
\hline No & BSu & Bsa & Prosedur \\
\hline 16 & mobile phone & telepon genggam & Pemadanan yang dikenal \\
\hline 17 & cardboard tubes ${ }^{*}$ & Kardus & $\begin{array}{l}\text { Pengurangan dan analisis } \\
\text { komponensial }\end{array}$ \\
\hline 18 & face value & Bernilai & Pengurangan \\
\hline 19 & Girlfriend & Pacar & Pemadanan yang dikenal \\
\hline 20 & record high & rekor tertinggi & Naturalisasi dan harfiah \\
\hline 21 & Workforce & tenaga kerja & Transposisi \\
\hline 22 & green ring* & lingkar hijau & Transposisi \\
\hline 23 & match-fixing ${ }^{*}$ & $\begin{array}{l}\text { pengaturan } \\
\text { pertandingan }\end{array}$ & Transposisi \\
\hline 24 & leading light & Tonggak & Pemadanan deskriptif \\
\hline 25 & Platform & Deretan & Pemadanan deskriptif \\
\hline 26 & two wheels* & kendaraan roda dua & Parafrase \\
\hline 27 & cycling capitals* & ibukota sepeda & Harfiah dan transposisi \\
\hline 28 & human rights & hak asasi manusia & Pemadanan yang dikenal \\
\hline 29 & Newspaper & surat kabar & Pemadanan yang dikenal \\
\hline 30 & Artworks & karya seni & $\begin{array}{l}\text { Pemadanan deskriptif dan } \\
\text { transposisi }\end{array}$ \\
\hline 31 & World Bank & Bank dunia & $\begin{array}{l}\text { Pemimjaman murni dan } \\
\text { transposisi }\end{array}$ \\
\hline 32 & world tour & tur dunia & Naturalisasi dan transposisi \\
\hline 33 & ice ag & jaman es & Naturalisasi dan transposisi \\
\hline 34 & Gunpoint & ancaman senjata & Pemadanan deskriptif \\
\hline 35 & Interior Ministry & $\begin{array}{l}\text { Kementrian Dalam } \\
\text { Negeri }\end{array}$ & Pemadanan yang dikenal \\
\hline 36 & Restroom & Toilet & Synonim \\
\hline 37 & oil painting & lukisan minyak & Transposisi \\
\hline 38 & nightworker* & kerja malam & Modulasi \\
\hline 39 & $\begin{array}{l}\text { for nightworking* } \\
\text { environment }\end{array}$ & $\begin{array}{l}\text { Suasana bagi para } \\
\text { karyawan yang bekerja } \\
\text { di malam hari }\end{array}$ & $\begin{array}{l}\text { Pemadanan deskriptif } \\
\text { penambahan }\end{array}$ \\
\hline 40 & pack ice & bongkahan es & Naturalisasi dan harfiah \\
\hline 41 & treasure- & penemuan harta karun & Transposisi \\
\hline 42 & polar bear & beruang kutub & Transposisi \\
\hline 43 & whistle-blower & pembocor rahasia & Pemadanan deskriptif \\
\hline 44 & Landlord & $\begin{array}{l}\text { pemilik rumah yang } \\
\text { dikontrakkan }\end{array}$ & Pemadanan deskriptif \\
\hline 45 & Healthcare & layanan kesehatan & Transposisi \\
\hline
\end{tabular}

* tidak/belum tercatat dalam kamus OALD 
Tabel 1 menunjukkan bahwa ada sepuluh kata majemuk yang tidak atau belum tercatat dalam kamus. Hal itu tentu saja menimbulkan masalah dalam penerjemahan. Tidak seperti frasa, makna kata majemuk tidak selalu merupakan gabungan makna unsur yang membentuknya (cf. Lieber, 2009: 47-9). Misalnya, two books dan two pencils yang merupakan frase dapat dengan mudah diterjemahkan ke dalam Bahasa Indonesia menjadi dua buku dan dua pensil. Sementara itu, kata majemuk two wheels yang dapat dilihat pada tabel 1 tidak diterjemahkan menjadi dua roda melainkan mejadi kendaraan roda dua. Dalam hal ini, prosedur yang dilakukan adalah parafrase, yakni membuat sesuatu yang implisit menjadi eksplisit.

Lain halnya dengan moneyloundering, green ring, treasure-find, match-fixing, dan cycling capital yang diterjemahkan menjadi pencucian uang, lingkar hijau, penemuan harta karun, pengaturan pertandingan, dan ibukota sepeda. Tampak bahwa setiap unsurnya diterjemahkan kata per kata yang kemudian diikuti dengan pengubahan bentuknya. Dengan demikian, prosedur yang dilakukan adalah prosedur transposisi. Empat kata majemuk pertama tersebut dimungkinkan karena terjemahannya sudah lazim dalam BSa, dan bahkan pencucian uang dan lingkar hijau juga sudah menjadi kata majemuk dalam BSa. Makna yang pertama tidak sama dengan frase lain yang menggunakan kata pencucian, seperti pencucian mobil dan pencucian motor. Terjemahan yang kedua, yakni lingkar hijau, menunjukkan bahwa bahwa kata tersebut merupakan kata majemuk dalam BSa karena kata lingkar umumnya digunakan bersama imbuhan seperti lingkaran atau melingkar. Sementara itu, kata majemuk cycling capital yang diterjemahkan dengan prosedur transposisi menjadi ibukota sepeda dapat menimbulkan ketidakjelasan makna dan tidak terasa seperti bahasa Indonesia.

Lebih jauh, Facebook yang merupakan kata majemuk nomina + nomina yang belum tercatat di dalam kamus tidak diterjemahkan. Dengan kata lain, penerjemahannya menggunakan prosedur peminjaman murni (transference). Hal itu dapat disebabkan oleh pertimbangan bahwa kata majemuk facebook merupakan merek dagang atau nama perusahan tertentu sehingga apabila diterjemahkan, terjemahannya bisa berdampak pada hasil penjualannya. Kata majemuk cardboard tube diterjemahkan menjadi kardus. Tampak bahwa tidak semua makna yang ada pada BSu termuat dalam BSa. Dengan demikian ada pengurangan makna dalam BSa. Dengan kata lain, prosedur yang digunakan adalah prosedur pengurangan (reduction).

Selanjutnya adalah nigthworker dan nightworking. Tampak bahwa kedua kata majemuk tersebut memiliki dasar (base) yang sama, yakni nightwork, tetapi prosedur penerjemahannya berbeda. Yang pertama diterjemahkan menjadi kerja malam yang sepadan dengan kata dasarnya tanpa ada makna akhiran -er. Terjemahan tersebut menunjukkan adanya pengubahan sudut pandang. Dengan demikian, prosedurnya adalah modulasi. Hal tersebut dapat disebabkan dampak makna dalam BSa jika nightworker diterjemahkan menjadi pekerja malam. 
Sementara itu, yang kedua diterjemahkan menjadi para karyawan yang bekerja di malam hari. Jelas bahwa prosedur yang digunakan adalah pemadanan deskriptif. Dengan demikian, tampak bahwa kata majemuk nomina + nomina yang baru atau yang belum tercatat dalam kamus dapat diterjemahkan dengan enam prosedur, yakni parafrase, transposisi, peminjaman murni, pengurangan, modulasi, dan pemadanan deskriptif.

Secara keseluruhan, tampak pada tabel 1 bahwa kata majemuk nomina + nomina diterjemahkan dengan 10 prosedur yang berbeda. Namun demikian, penerjemahan beberapa kata majemuk, yang sudah tercatat pada kamus, pada tabel 1 menunjukkan bahwa penerjemah kurang menyadari keberadaan kata majemuk. Hal itu ditunjukkan oleh beberapa terjemahannya, misalnya queue-jumping menjadi melompat di antrean. Tampak bahwa penerjemahannya dilakukan dengan cara kata per kata yang diikuti prosedur transposisi, sehingga terjemahannya menimbulkan makna ganda. Dalam hal ini, pembaca dapat memaknai kata majemuk tersebut menjadi seseorang yang melompat di tempat dalam sebuah antrean atau seseorang yang melompati orang lain yang sedang mengantre di depannya atau dibelakangnya. Sebenarnya, kata majemuk tersebut sudah sangat jelas didefinisikan dalam kamus. Jika melihat kamus, penerjemah seharusnya bisa menggunakan prosedur parafrase sehingga terjemahannya menjadi menyerobot (antrean).

\section{Kata Majemuk Adjektif + Nomina \\ Kata majemuk adjektiva +} nomina termasuk dalam salah satu kata majemuk nomina (McCarthy, 2002: 613). Kata majemuk jenis ini terdiri atas dua unsur, yakni adjektif dan nomina. Hasil penelitian menunjukkan bahwa frekuensi penggunaan kata majemuk jenis ini menempati posisi kedua. Dengan kata lain, kata majemuk jenis ini merupakan kata majemuk yang cukup sering digunakan dalam teks berita berbahasa Inggris. Keseluruhan kata majemuk adjektif + nomina dan prosedur penerjemahannya yang teridentifikasi dari sumber data dapat dilihat pada tabel 2 berikut ini.

Tabel 2 Kata Majemuk Adjektiva + Nomina dan Prosedur Penerjemahannya

\begin{tabular}{|c|c|c|c|}
\hline No & BSu & Bsa & Prosedur \\
\hline 1 & prime minister & perdana mentri & Harfiah \\
\hline 2 & Wrongdoing & Kesalahan & Pengurangan \\
\hline 3 & White House & Gedung Putih & $\begin{array}{l}\text { Pemadanan } \\
\text { dikenal }\end{array}$ \\
\hline 4 & Superbugs & resistensi antibiotik & Pemadanan deskriptif \\
\hline 5 & $\begin{array}{l}\text { midle-income* } \\
\text { countries }\end{array}$ & $\begin{array}{l}\text { negara miskin } \\
\text { berkembang }\end{array}$ & Parafrase \\
\hline 6 & recreational use* & konsumsi secara umum & Parafrase \\
\hline 7 & Gold Rush* & $\begin{array}{l}\text { Saat banyak orang } \\
\text { menemukan kandungan } \\
\text { emas di sejumlah wilayah }\end{array}$ & Pemadanan deskriptif \\
\hline
\end{tabular}




\begin{tabular}{|c|c|c|c|}
\hline No & BSu & Bsa & Prosedur \\
\hline 8 & top flight & papan atas & $\begin{array}{l}\text { Pemadanan } \\
\text { dikenal }\end{array}$ \\
\hline 9 & The Foreign Office & Departemen Luar Negeri & $\begin{array}{l}\text { Pemadanan } \\
\text { dikenal }\end{array}$ \\
\hline 10 & Highway & Jalan tol & $\begin{array}{l}\text { Pemadanan } \\
\text { dikenal }\end{array}$ \\
\hline 11 & The United Nation & Persatuan Bangsa Bangsa & Harfiah \\
\hline 12 & Royal Society & Royal Society & Peminjaman murni \\
\hline 13 & Masterpieces & karya besar & $\begin{array}{l}\text { Pemadanan } \\
\text { dikenal }\end{array}$ \\
\hline 14 & prime minister & perdana mentri & Harfiah \\
\hline 15 & hard time* & masa sulit & Transposisi dan sinonim \\
\hline 16 & keen vision* & Keinginan & Pengurangan \\
\hline 17 & prime-time showing & jam tayang utama & $\begin{array}{l}\text { Parafrase } \\
\text { Tansposisi }\end{array}$ \\
\hline 18 & $\begin{array}{l}\text { Abominable } \\
\text { Snowman }\end{array}$ & \begin{tabular}{lrr} 
Abominable & \multicolumn{2}{c}{ Snowman } \\
(manusia & salju & yang \\
mengerikan) & &
\end{tabular} & Penerjemahan berlabel \\
\hline 19 & $\begin{array}{l}\text { mixed-gender* } \\
\text { swimming lesson }\end{array}$ & Kelas berenang gabungan & Pengurangan \\
\hline 20 & gold visa* & visa emas & $\begin{array}{l}\text { Peminjaman murni dan } \\
\text { transposisi }\end{array}$ \\
\hline
\end{tabular}

* tidak terdapat dalam kamus OALD

Tabel 2 menunjukkan bahwa ada 20 kata majemuk jenis ini dan ada 9 prosedur yang digunakan dalam penerjemahannya ke dalam bahasa Indonesia. Tampak juga bahwa ada tujuh kata majemuk yang baru atau yang belum tercatat dalam kamus. Yang pertama adalah middle-income yang diterjemahkan menjadi miskin dan berkembang. Tampak bahwa makna middle-income yang secara harfiah bermakna 'pendapatan menengah' menjadi cenderung tersurat dalam BSa. Dengan demikian, dapat dikatakan bahwa prosedur yang digunakan adalah prosedur parafrase. Yang kedua adalah recreational use yang diterjemahkan menjadi konsumsi secara umum. Hal yang sama tampaknya terjadi juga dalam penerjemahan kata majemuk ini, yakni makna BSa lebih tersurat. Dengan demikian prosedurnya adalah parafrase. Selanjutnya adalah Gold Rush yang diterjemahkan menjadi saat banyak orang menemukan kandungan emas di sejumlah wilayah. Jelas bahwa prosedur yang digunakan di sini adalah pemadanan deskriptif.

Tampak juga bahwa prosedur transposisi dan sinonim (termasuk dalam prosedur couplet) dapat digunakan dalam penerjemahan kata majemuk adjektif + nomina yang belum tercatat dalam kamus, seperti hard time menjadi masa sulit. Sementara itu, prosedur pengurangan juga terjadi dalam penerjemahan kata majemuk yang belum tercatat dalam kamus, yakni 
keen vision dan mixed-gender yang diterjemahkan menjadi keinginan dan gabungan. Kedua terjemahan ini hanya mencakup salah satu makna yang ada pada salah satu unsur BSu, terutama makna unsur yang didepannya. Tampaknya penerjemah menemukan kesulitan sehingga makna salah satu unsur BSu tidak tersampaikan oleh terjemahannya, terutama pada kata majemuk keen vision. Sebenarnya, pada kata majemuk mixed-gender, pengurangan tersebut dapat dimengerti jika penerjemah menggunakan prosedur terjemahan yang dikenal (recognized translation), yakni campuran sehingga terjemahan keseluruhannya menjadi kelas berenang campuran seperti halnya bulu tangkis ganda campuran yang sudah dikenal luas dalam konteks olah raga.

Yang terakhir adalah gold visa yang diterjemahkan menjadi visa emas. Tampak bahwa ada peminjaman murni pada kata visa dan pengubahan struktur dalam terjemahannya. Dengan kata lain, penerjemahannya menggunakan dua prosedur, yakni prosedur peminjaman murni dan transposisi. Dengan demikian, dapat dikatakan bahwa ada lima prosedur yang digunakan dalam penerjemahan kata majemuk adjektif + nomina yang belum tercatat dalam kamus, yakni prosedur parafrase, pemadanan deskriptif, transposisi, penggunaan sinonim, dan pengurangan. Namun, secara keseluruhan, tabel 2 menunjukkan bahwa ada sembilan prosedur yang digunakan dalam penerjemahan kata majemuk adjektiva + nomina dalam Bahasa Inggris ke dalam Bahasa Indonesia.

Terlepas dari hal itu, tampak juga bahwa ada terjemahan yang menunjukkan kurangnya perhatian atas keberadaan kata majemuk dalam teks berita, yakni wrongdoing yang diterjemahkan menjadi kesalahan. Dalam hal ini, kata majemuk wrongdoing sebenarnya sudah jelas didefinisikan dalam kamus, yakni illegal or dishonest behaviour. Oleh karena itu, seharusnya kata majemuk tersebut diterjemahkan dengan prosedur komponensial analisis sehingga menjadi tindakan ilegal atau kecurangan.

\section{Kata Majemuk Verba + Nomina}

Kata majemuk verba + nomina merupakan salah satu kata majemuk nomina yang memiliki unsur verba yang diikuti oleh nomina. Hasil penelitian menunjukkan bahwa hanya ada satu kata majemuk jenis ini. Kata majemuk tersebut adalah swimsuit dan diterjemahkan menjadi baju renang. Tampak bahwa penerjemahan kata majemuk tersebut dilakukan pada tataran kata dan diikuti pengubahan struktur pada BSa. Pendek kata, prosedur yang digunakan adalah prosedur transposisi.

\section{Kata Majemuk Preposisi + Nomina}

Kata majemuk preposisi + nomina juga merupakan salah satu kata majemuk nomina yang memiliki unsur preposisi yang diikuti oleh nomina. Seperti halnya kata majemuk verba + nomina, hasil penelitian juga menunjukkan bahwa hanya ada satu kata majemuk jenis ini. Kata majemuk tersebut adalah outcry. Tampak bahwa penerjemahan kata majemuk jenis ini diterjemahkan dengan salah satu komponen makna yang ada pada kata cry. Dengan kata lain, prosedur yang 
digunakan adalah prosedur analisis komponensial.

\section{PENUTUP}

Berdasarkan analisis data, ada beberapa hal yang dapat disimpulkan. Pertama, kata majemuk nomina dalam bahasa Inggris merupakan kata majemuk yang sering digunakan dalam teks berita. Hal ini ditunjukkan dengan adanya 67 kata majemuk nomina dari lima puluh enam teks berita. Pembentukan kata majemuk nomina merupakan proses pembentukan leksem yang cukup produktif. Hal tersebut didasari oleh tujuhbelas leksem yang merupakan kata majemuk nomina baru atau kata majemuk yang belum tercantum dalam kamus.

Kedua, berdasarkan kategori unsur yang membangunnya, keseluruhan kata majemuk yang digunakan tersebut dapat diklasifikasikan menjadi empat jenis. Kata majemuk nomina yang memiliki unsur adjektif + nomina merupakan kata majemuk nomina yang paling produktif. Hal tersebut ditunjukkan dengan adanya 7 kata majemuk baru dari jumlah keseluruhan yang mencapai 20 kata majemuk.

Ketiga, ada dua belas prosedur penerjemahan yang digunakan dalam proses penerjemahan kata majemuk bahasa Inggris ke dalam bahasa Indonesia.

Tiga prosedur penerjemahan sangat sering digunakan baik dalam penerjemahan kata majemuk nomina yang sudah tercantum dalam kamus maupun kata majemuk yang belum tercantum dalam kamus. Tiga prosedur tersebut adalah prosedur transposisi, pemadanan deskriptif, dan parafrasa.
Tampak pula beberapa kata majemuk belum diperhatikan keberadaannya oleh penerjemah. Karena itu, penerjemah atau calon penerjemah sebaiknya lebih berhati-hati dalam menerjemahkan sebuah teks dengan memperhatikan keberadaan kata majemuk, yang secara bentuk sama dengan frasa, tetapi memiliki kandungan semantis yang berbeda dengan frasa.

$\begin{array}{lr}\text { Untuk penelitian } & \text { selanjutnya, } \\ \text { korpus diharapkan } & \text { dapat }\end{array}$ mengakomodasi data yang lebih luas sehingga hasil penelitian menjadi lebih representatif. Dampak penggunaan prosedur terhadap hasil terjemahan juga belum dilakukan dalam penelitian ini. Dengan demikian, peneliti selanjutnya sebaiknya mengkaji proses penerjemahan kata majemuk bahasa Inggris ke dalam bahasa Indonesia lebih dalam lagi.

\section{DAFTAR PUSTAKA}

Benczes, Reka. 2005. Creative Compounding in English. Amsterdam: John Benjamin Publishing Company.

Biber, Douglas, Stig Johansson, Geoffrey Leech, Susan Conrad, dan Edward Finegan. 1999. Longman Grammar of Spoken and Written English. London: Longman.

Bauer, Laurie. 1988. Introducing Linguistic Morphology. Edinburgh: Edinburgh University Press.

Harley, Heidy. 2006. English Words: A Linguistics Introduction. Malden: Blackwell Publishing.

Harmelink, Bryan. 2012. "Lexical Pragmatics and Hermeneutical Issues in the Translation of Key 
Terms". Journal of Translation. 8 (1). 25-35. Tersedia di http://www.sil/org/resources/publicat ions/entry/48938

Hoed, Beny H. 2006. Penerjemahan dan Kebudayaan. Jakarta: Dunia Pustaka Jaya.

Katamba, Francis. 1993. Morphology. Basingstoke: Macmillan.

Kuncara, S. D., M. R. Nababan dan S. Samiati. 2013. "Analisis Terjemahan Tindak Tutur Direktif pada Novel The God Father dan Terjemahannya dalam Bahasa Indonesia". Transling Journal: Translation dan Linguistics. 1 (1). 1 20. Tersedia di http://www. Jurnal.pasca.uns.ac.id
Libben, G. dan G. Jarema (ed). 2006. The Representation and Processing of Compound Words. Oxford: Oxford University Press.

Lieber, Rochelle. 2009. Introducing Morphology. Cambridge: Cambridge University Press.

Matthews, P. H. 1991. Morphology. $\left(2^{\text {nd }}\right.$ edition). Cambridge: Cambridge University Press.

McCharty, Andrew C. 2002. An Introduction to English Morphology: Words and Their Structure. Edinburgh: Edinburgh University Press.

Newmark, P.1988. A Text Book of Translation. New York: Prentice Hall. 